Copyright (C) 2018 by Academic Publishing House Researcher s.r.o.

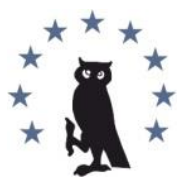

Published in the Slovak Republic

Media Education (Mediaobrazovanie)

Has been issued since 2005

ISSN 1994-4160

E-ISSN 1994-4195

2018, 58(3): 39-62

DOI: $10.13187 / \mathrm{me} .2018 .3 \cdot 39$

www.ejournal53.com

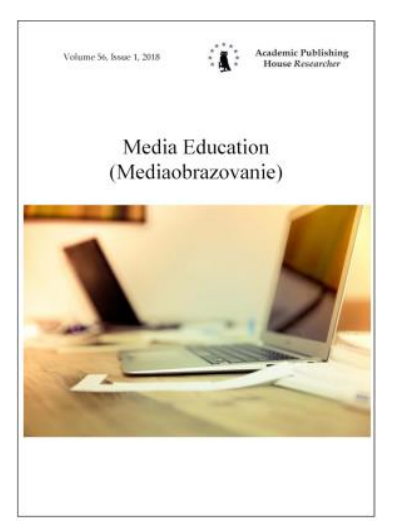

\title{
Comparative analysis of the development of mass media education in the Commonwealth of Independent States (CIS) countries
}

\author{
Alexander Fedorov a, * , Anastasia Levitskaya ${ }^{\mathrm{b}}$ \\ a Rostov State University of Economics, Russian Federation \\ $\mathrm{b}$ Taganrog Institute of Management and Economics, Russian Federation
}

\begin{abstract}
Analysis of the development of mass media education in the CIS countries showed that the main sections of the contents of the media education program (the existence of a section depends on the age and professional status of the audience) can be presented in the following way: the place and role, media and media education functions in the modern society, types and genres, media languages; basic terms, concepts related to media culture; historical stages of development of media culture in the world; analysis and evaluation of the functioning of media and media texts of different types and genres in the socio-cultural and ideological contexts; technologies of creation and distribution of media texts of various kinds and genres. Areas of application of such programs are: schools, secondary special educational institutions, universities, advanced training courses, additional education institutions and leisure centers; distant media education courses aimed at various population groups; independent (continuous/lifelong) media education, for example, through Internet sites. Modern models of media education in the CIS countries (with all the diversity of age and professional whole groups of the population) contain diagnostic, contenttargeted and effective components.

Thereat, the author of the article believes that the CIS countries should not build the development of mass media education of their citizens based on confrontation and ideological propaganda. Thematical units of media education syllabi should evenly give the audience an idea that there is no single supreme democratic state in the world with ideally objective mass media. That is why the basis of media education activity must be sociocultural concepts (including, of course, analytical and practical components) rather than ideological ones that will allow the audience to comprehensively master the ambiguous world of media culture.

Keywords: media education, media competence, media literacy, media pedagogy, media, model, CIS, school, university, society.

\section{Introduction}

Analysis of the development of mass media education in the CIS countries (Akhmetova, 2011; 2012; 2014; 2016; Baranov, 2002; Beknazarova, 2011; Bondarenko, 2009; Chelysheva, 2008; Fateeva, 2007; Gabor, 2002; Gendina, 2017; Gudilina, 2007; Gumenyuk, Potapova, 2015; Hilko, 2007; Ismayilova, 2016; Ivanov, Ivanova, 2013; Kirillova, 2012; Korkonosenko, 2004; Korochensky, 2005; Koropatnik, 2015; Kovbasco, 2013; Kulinsky, 2010; Mokroguz, 2013;

\footnotetext{
* Corresponding author

E-mail addresses: 1954alex@mail.ru (A. Fedorov), a.levitskaya@tmei.ru (A. Levitskaya)
} 
Naydyonova, 2013; Nuraliev, 2010; Onkovich, 2009; Pocheptsov, 2015; Robak, 2002; Sakhnevich, 2010; Sharikov, 2012; Spichkin, 1999; Vartanova, Zasursky, 2003; Venidiktov, 2015; 2017; Vozchikov, 2007; Zaznobina, 1998; Zhizhina, 2009; Zhurin, 2009, etc.) shows that it is advancing unevenly.

Regarding the intensity and levels of development of media education, the CIS countries can be divided into three groups: 1) countries with a relatively high level of development of mass media education (theoretical researches, practical implementation): Russia and Ukraine; 2) countries with medium level of development of mass media education (Belarus, Kazakhstan, Armenia), 3) countries with low level of mass media education development (Azerbaijan, Kyrgyzstan, Moldova, Tajikistan, Turkmenistan, Uzbekistan). Being part of the CIS till August 18, 2009, Georgia also, in our opinion, belonged to the third group.

Our assessment of the current situation can be verified by the findings of researchers from the CIS countries. For example, K. Ismayilova notes that "in Uzbekistan the state of media education today can be characterized as being in the stage of formation. There is no concept of a national model for the development of media education; there is no single system of media pedagogy. Media education projects are more evident in informal education (trainings of nonstate educational institutions, advanced training courses, etc.). There are not enough specialists capable of effectively educating media literacy" (Ismailova, 2016: 124). In the "Report on the results of the study of the level of media literacy in the Kyrgyz Republic" (a survey of the population over 16 in the Kyrgyz Republic was conducted from September 1 to November 30, 2017, 1200 urban and rural respondents from seven regions were interviewed) (Report..., 2018: 11) states that in Kyrgyzstan "the topic of media literacy is relevant and challenging. The existing activities to increase the level of media literacy as a skill and the development of media literacy as a science are both at a rudimentary stage" (Report..., 2018: 94). A similar situation is currently observed in Azerbaijan and Tajikistan (Tajidinov, Rustamov, Kosimov, Ibodova, 2010) and Turkmenistan...

In terms of practical implementation of mass media education in schools by the end of the second decade of the 21st century, the primacy undoubtedly belongs to Ukraine, where in 2010 the "Concept of introducing media education in Ukraine" was adopted (Concept..., 2010), and in 2011 a large-scale experiment of integrating media education programs in dozens of Ukrainian schools. Nevertheless, since 2014, the process of media education development in Ukraine has acquired a specific character, as it will be discussed in more detail below.

Despite significant advances in research and publications in media education field (Baranov, 2002; Bondarenko, 2009; Chelysheva, 2008; Fateeva, 2007; Gendina, 2017; Gudilina, 2007; Hilko, 2007; Kirillova, 2012; Korkonosenko, 2004; Korochensky, 2005; Sharikov, 2012, Spichkin, 1999; Vartanova, Zasursky, 2003; Vozchikov, 2007; Zaznobina, 1998; Zhizhina, 2009; Zhurin, 2009, etc.), the practical implementation of mass media education in Russia is still of a sporadic nature and in many ways continues to depend on the efforts of enthusiasts.

\section{Materials and methods}

Materials of our research are academic writings on media literacy education, and media competence published in a variety of countries, the CIS countries foremost, as well as Internet sites, and evidence of the practical application of media education in the CIS countries, accumulated from 1992 to the present day. Methodology is based on theoretical framework on the relationship, interdependence and integrity of the phenomena of reality, the unity of the historical and the logical in cognition, the theory of the dialogue of cultures by M. Bakhtin - V. Bibler (taking into account the theoretical concepts developed by such well-known researchers as Y. Lotman, U. Eco and others). The research is based on a content approach (identifying the content of the process being studied, with due regard to the aggregate of its elements, interaction between them, their nature, access to facts, analysis and synthesis of theoretical conclusions, etc.) and a comparative approach.

The following methods are used: data collection (dissertations, extended abstracts of Ph.D. dissertations, monographs, articles, reports) related to the project's theme, analysis of academic literature, theoretical analysis and synthesis; generalization and classification; content analysis. 


\section{Discussion}

Countries with a relatively high level of mass media education development

Russia

Since there is a special article devoted specifically to the state of media education in Russia (Fedorov, Levitskaya, 2018), in this article we only note that, unlike Ukraine, the relatively high Russian level of media and information literacy development is manifested mainly not at the level of practical implementation, but at the theoretical and methodological levels (Baranov, 2002; 2008; Bondarenko, 2009; Chelysheva, 2008; Fateeva, 2007; 2015; Fedorov et al., 2014; Fedorov, 2001; 2003; 2007; 2009; Fedorov, 2003; Fedorov, Chelysheva, 2002; Fedorov, Novikova, 2005; Fortunatov, 2009; Gendina, 2013; 2017; Gudilina, 2007; Hilko, 2007; Kirillova, 2005; 2012; Korkonosenko, 2004; Korochensky, 2003; 2005; Levitskaya et al., 2016; Polat, 2001; Sharikov, 2005; 2012; Silverblatt, Fedorov, Levitskaya, 2016; Soldatova et al., 2013; Spichkin, 1999; Tsymbalenko, Sharikov, Shcheglova, 2006; Vartanova, Zasursky, 2003; Vozchikov, 2007; Zadorin et al., 2017; Zaznobina, 1998; Zhizhina, 2009; Zhurin, 2009, etc.), although in recent years there has been a growing expansion into the practical field in this area.

Ukraine

For quite a long time (1992-2013), Ukraine was in a situation of the country, strongly influenced by the Russian media education experience, including the academic developments of our research school (Balyk, 2012: 171-177; Bondur, 2008: 33-36; Burim, 2012: 155-162; Chemeris, 2006: 104-108; Cherepovska, 2009: 15-26; Gurinenko, 2009: 181-184; Ivanov, Ivanova, 2013: 2544; Ivanov, Shkoba, 2012: 41-52; Kazakov, 2007; 2009: 88-94; Kosyuk, 2005; Lozitska, 2009: 6065; 2010: 60-66; Oleksyuk, Shubenko, 2009: 77-87; Onkovych, 2007: 357-363; 2008: 165-177; 2009: 252-255, 327-333; Sakhnevich, 2010: 239-242; Sheguta, 2013: 10-12; Trohanyak, 2007: 5457; Voloshina, 2010: 510-517; Zakharchuk, 2010: 145-151 and others). One of the articles published in Kiev was specifically dedicated to the activities of our research school "Media Education and Media Competence" (Kovbasko, 2013: 210-218).

The media education experience of UNESCO, and Western countries, also actively rendered in Ukraine (Barishpolets, 2008: 162-170; Cheremis, 2012: 124-130; 2013: 215-221; Dub, 2012: 4-5; Ivanov, Ivanova, 2013: 25-44; Ivanov, Voloshenyuk, Kulchynska, 2011; Moroz, 2011; Onkovych, 2010: 119-128; Robak, 2002: 70-92; Trohanyak, 2008: 55-62; Vasyanovich, 2007: 11-21, etc.).

Comparative studies were also attempted. For example, levels of media literacy of Polish and Ukrainian students were compared: 54 students from Wroclaw University and 42 students from Lviv National University participated in the experiment (Trohanyak 2009: 41). The findings showed that $71 \%$ of Lviv students do not know anything about media education, identifying it with distant education; they did not take any courses on media education at the university. Polish students, on the contrary, had the opportunity to attend the media education course, so $78 \%$ of the respondents in this group were able to correctly identify the tasks of media education (Trohanyak 2009: 45).

A similar analysis was made upon detecting the levels of media literacy of the youth in Slovakia and Ukraine in 2004-2008. The authors of the study used quantitative methods questionnaires and written tests with subsequent meaningful analysis. The Slovak sample consisted of 674 respondents, of which 206 were university students, 188 were graduate students and 180 were students of other years of study. In Ukraine (in 2004), the sample was 2003 respondents aged 14 to 35 . The related study with a slightly modified toolkit was conducted in 2007. The results of the research attested to the fact that Ukrainian youth lagged behind Slovak peers in terms of media literacy (Afanasyev, 2010: 45-47).

In connection with the experimental introduction of media education in Ukrainian schools, 93 teachers of primary, secondary and high schools were surveyed (the majority of the respondents were female $-78 \%$ ) (Mokroguz 2013: 426).

Therewith, the interviewed Ukrainian teachers prioritized media education objectives as follows:

- protection against harmful media influence, for example, from the impact of violent scenes on the screen, from propaganda of "bad taste", from works of low artistic quality, etc. (74.5\%);

- development of critical thinking of the individual in relation to media (62.8\%);

- preparing people to live in a democratic society (61.6\%); 
- development of "good" aesthetic taste, evaluation of aesthetic qualities of media texts, appreciation of masterpieces of media culture (58.8\%);

- development of the audience's ability to conduct the moral values, psychological analysis of various aspects of media, media culture $(55.8 \%)$;

- teaching the audience practical skills to use media technology (38.1\%);

- development of personal communication skills (37.3\%); (31.7\%);

- development of skills of self expression with the help of media, media texts creation

- development of the audience's ability to perform political, ideological analysis of various aspects of media, media culture (31.3\%);

- development of the audience's ability to analyze media texts in a broad cultural and sociocultural context ( $28.5 \%)$;

- satisfaction of various audience's needs in the field of media (16.1\%);

- development of the audience's ability to perceive, understand and analyze media language (audiovisual level, composition, stylistics, symbols, etc.), to "decode" media texts (11.9 \%);

- teaching the theory of media and media culture ( $9.8 \%$ ); 427-428).

- teaching the history of the media, the history of media culture (3.8\%) (Mokroguz, 2013:

Since this survey was conducted on the basis of the questionnaires developed by our research team (Fedorov, 2007), we can compare the results obtained in Ukraine with the similar results of the questionnaire survey of Russian educators (Fedorov, 2007: 170-180), where teachers from Russia ranged the most crucial objectives of media education as follows:

- development of critical thinking (the main task is: development of critical thinking, autonomy of an individual in relation to media / media texts) $-63.2 \%$;

- development of aesthetic perception, taste, abilities for competent evaluation of aesthetic quality of media texts, understanding; propaganda of masterpieces of media culture $-57.9 \%$;

- development of the audience's ability to political, ideological analysis of various aspects of media / media culture $-50.9 \%$;

- development of the audience's ability to analyze media texts in a broad cultural and sociocultural context $-43.8 \%$;

- teaching the audience practical skills to use media technology - $43.8 \%$;

- development of the audience's ability to perceive, understand and analyze media languages $-36.8 \%$;

- protection of the audience from harmful media influence - 35.1\%;

- equipping people to live in a democratic society with the help of media / media culture- $35.1 \%$;

- satisfying the needs of the audience - 33.3\% (Fedorov, 2007).

A comparative analysis of the opinions shows that while the Ukranian teachers prioritize protective tasks $(74.5 \%)$, their Russian colleagues appreciate the development of students' critical thinking (63.2 \%), and meanwhile only $35 \%$ of them attach more importance to innoculatory approach. However Ukrainian teachers (as, in fact, Western European countries) appreciate the task of preparation people for participation in a democratic society (61.6\%), whereas only one in three Russian educators share this priority.

But with respect to the need to develop a good aesthetic taste, assess the aesthetic qualities of media texts; understand media texts, masterpieces of media culture, the viewpoints of Ukrainian and Russian teachers are very close (58.8 \% and $57.8 \%)$.

It was revealed that the interviewed teachers believe that media education of schoolchildren should be compulsory (65\% in Ukraine, $63 \%$ in Russia) as integrated in basic school disciplines ( $44.9 \%$ in Ukraine, $45.6 \%$ in Russia), as a separate subject (32.3\% in Ukraine, $24.5 \%$ in Russia) or as the synthesis of autonomous and integrated lessons (20.2 \% in Ukraine, $50.8 \%$ in Russia). Approximately one third of teachers ( $28.8 \%$ in Ukraine, $34.8 \%$ in Russia) think that the media education of schoolchildren should be optional or extra-curricular. Only $3.6 \%$ of teachers - in Ukraine and $14 \%$ - in Russia resist the idea of schoolchildren's media education (Mokroguz, 2013: 430; Fedorov, 2007). As one can see, there are very similar trends.

It was found that only $3.2 \%$ of Ukrainian teachers used elements of media education in each lesson. More common were the following answers: at 1-2 lessons on the topic (24.2 \%), at 1-2 lessons per quarter (32.3\%), at 1-2 lessons a semester (16.4\%), at $1-2$ lessons a year (22.2 \%). Only 
$1.7 \%$ of teachers stated that they have never integrated media education in their lessons (Mokroguz 2013: 434). In Russia, $28.2 \%$ of teachers said that media education is used to a greater or lesser extent in the classroom, but the percentage of teachers not involved in media education was much higher - 25.6\% (Fedorov, 2007).

Among the obstacles to using the elements of media education in the lessons, the teacher mentioned the following: little knowledge on the theory and methodology of media education (65.8 \% in Ukraine, $54.3 \%$ in Russia), time consuming lesson planning ( $42.5 \%$ - in Ukraine), lack of own media skills (33.1 \% in Ukraine, $24.5 \%$ in Russia), lack of school officials' support and guidance (28.3 \% in Ukraine, $77.2 \%$ in Russia), absence of financial incentives (3,6 \% - in Ukraine, - 89,4 \% in Russia) (Mokroguz, 2013: 435; Fedorov, 2007). As we can see, with the relative similarity of some points, Russian teachers demonstrated more interest in opportunities of fundrising and more sensitive to authorities' impact.

Of course, during this period it is possible to distinguish some authentic scientific and methodological developments of Ukrainian colleagues: G.G. Pocheptsov and V.F. Ivanov published many works devoted to mass communications, media influences and information wars (Ivanov, 2009-2010; Pocheptsov, 1999; 2000; 2001; 2011, etc.). B. Potiatynik and N. Gabor tried to find their way in media education with an emphasis on media ecology (Potiatinik, 2004; Gabor, 2002), G.V. Onkovych developed the concept of media didacticts (Onkovych, 2009; Onkovych, 2013: 7989; Onkovych et al., 2013). Thus, in Ukraine in recent decades there have developed several directions for interpreting the goals and objectives of media education. The most prominent are Kiev group, which we conventionally refer to as the group of "media didactics" (G. Onkovych, V. Ivanov, etc.), Lviv school of "media ecology" (B. Potiatinik, N. Gabor, etc.) and Mariupol school of "media criticism" (G. Pocheptsov and others). These three centers can be attributed to some degree to the "enlightening effect" of media education. In contrast to them, Kharkiv National University adopted an alternative media education model, in which the emphasis is on the aesthetic component of media and visual communications (Bakirov, Starodubtseva, 2013: 51).

Taking into account the Russian and Western experience, media pedagogues of Ukraine began to develop teaching manuals (especially vigorously upon the beginning of a large-scale experimental introduction of media education in Ukrainian schools) (Basics..., 2014; Cherepovska, 2010; Media culture..., 2009; Practical ..., 2013; Sakhnevich, 2010; Media education ..., 2012; 2014, etc.). More and more scientific-methodical conferences were organized to involve Ukrainian educators in the media education process (Collection of ..., 2013; 2015; 2017; Materials..., 2013; Media culture..., 2008, etc.).

However, since the spring of 2014, especially in connection with the formation of DNR (Donetsk People's Republic) and LNR (Lugansk People's Republic) military operations on their borders, mass media education in Ukraine has increasingly assumed an ideological color. The early signs of these changes were visible in the article by Y. Emets-Dobrnosova with the eloquent title "Media Education" according to the Kremlin's recipe" (Emets-Dobronosova, 2014). The author declared substantially unsupported claims that "a vivid example of the multidimensionality of the Kremlin's technologies" was the "negative influence" of Russia on the development of media education in Ukraine: "Ukrainian scientists' embeddidness in the Russian context of the development of media education is impressive. They regularly and in sufficient scale speak not at international forums on media education, but at Russian conferences. Immediately after the start of the program on the development of media education in Ukraine, seminars and trainings were launched, with only one nuance - under the paternal leadership of Russian specialists. Even the history of media education worldwide most Ukrainian pioneer scientists in this field have studied with the mediation of Russian publications" (Emets-Dobronosova, 2014).

It is unclear how the studies of Russian acknowledgement of international theory and practice of media education, and Russian experience in media education in itself, can do any harm to Ukranian researchers in the field.

It should be noted that the above criticism was promptly taken into account by Ukrainian media educators. For example, textbooks on media education, published in Kiev in 2017 (Authors' ..., 2017; Parents..., 2017; Media Literacy..., 2017), are mostly based on Western resources, they have almost no references to the Russian experience.

Moreover, as early as in 2015, in Ukraine, a number of articles were published which message was to change the media education concept in Ukraine, giving now the priority of ideological and 
information confrontation. So M. Koropatnik in the article "Peculiarities of media education in the conditions of the "hybrid war" of Russia against Ukraine" expresses indignation that media education in Ukraine "continues to be based mainly on traditional positivistic educational principles without taking into account the mass media's propaganda pressure on the consciousness of people of different age categories with a sufficiently powerful manipulative potential. But in response to the aggressive information environment, there is a need for a deeper analysis of the characteristics of information, disinformation and propaganda wars in order to consider them in the practice of media education, especially in terms of increasing its effectiveness in the process of socialization of the individual. ... There is the basis for this - the Ukrainian model of media education that integrates the best world experience: Canadian (development of critical thinking), French (civic education), American (priority of creativity vs. authoritarian approach in education), British (combination of protective model of "vaccination" and aesthetic development). The prerequisites for achieving one of the most important tasks of media education in the current conditions is to develop critical thinking, the ability to understand the hidden meaning of messages, and to resist the manipulation of the individual's consciousness by the media-create an ideological theory of media education and the theory of media education as a means of critical thinking development" (Koropatnik, 2015: 18-21).

Similar ideas were developed by M. Koropatnik and in his article "Problems of forming media competence of the population in Ukraine regarding the events in the Crimea and Donbass in the context of Russia's information and propaganda aggression" (Koropatnik, 2015: 357-372), in which the author for some reason does not provide analysis why Ukraine, having become the victim of the "aggressor" in the opinion of the Kiev regime in 2014, has not only maintained diplomatic relations with Russia for four years, but does not withdraw from the CIS (although there are projects of the cessession), does not cut the "hostile" gas pipe passing through its territory; does not require the immediate return home of millions of Ukrainian labor migrants who work in Russia, etc. And if we go back from politics to the topic of media education, one can witness that in 2018 , in spite of the position of Kiev's authorities; a lot of Ukrainian media educators continue to submit their articles to Russian academic journals.

Anti-Russian attitude also permeats the article by N. Cherepovska, categorically asserting that "information aggression aimed at Ukraine from the hostile state is aimed at ceizing the consciousness of the society, exercising control over it and managing the public opinion of Ukrainians according to its imperial goals. The adequacy of the perception of hostile propaganda and the corresponding resistance to media informational influences on the part of our citizens is a serious social and psychological problem. Its essence lies in the disparity of a large-scale, professionally prepared, purposeful hostile indoctrination as an attack on the identity of Ukrainians, on the one hand, and the lack of an effective tool that can provide the opportunity to provide psychological resistance to harmful information to the general public, on the other hand" (Cherepovska, 2015: 60).

Thus, some Ukrainian media educators and ideologists decided that "war is a high time for media education" (Dorosh, 2014) and began to turn it into an instrument of anti-Russian propaganda.

And thus, media education manual for librarians in the spirit of standard propaganda of the Ukrainian pro-Western regime established in 2014, states that "dramatic events in our country connected with the revolution of dignity, the death of the heavenly hundred, further armed aggression of Russia and the annexation of part of the territory of Ukraine, firmly riveted millions of people to news reports, forced them to monitor information around the clock - almost live, in order to constantly be aware of, to make relevant conclusions and act. Many of our fellow citizens, perhaps for the first time in their lives, became so dependent on news. Therefore, as never before, the question of journalistic standards, responsible media and, at the same time, competent, literate reflection of everything that we learn about from various media has emerged in Ukrainian society. Often their goal is not to inform, but on the contrary - to misinform, to broadcast false, so to speak, fake information, as, for example, in the notorious reports on the Russian Channel 1" (Gumenyuk, Potapova, 2015). At the same time, the authors of the manual seem to seriously believe that false and unverified information only comes from Russia, whereas Western and Ukrainian leading media sources allegedly always the truth, the whole truth and nothing but the truth... 
Another Ukrainian publication exhibits the similar approach: "Media literacy of citizens. The teaching manual for coaches" (Training ..., 2015).

Needless to say, Russian media are not perfect, however, at the present time almost every central television channel in Russia broadcasts live political and sociocultural discussions on a daily basis with the participants of American, German, Polish, other European countries and Ukrainian journalists and political scientists who openly express their anti-Russian views, sharply criticize Russian authorities, etc. Thus, there is much more freedom of speech on Russian television than in the Ukrainian one, where Russian journalists and political scientists of non-liberal orientation are not allowed to take part in television debates or political talk shows.

Another textbook for teachers published by the Academy of the Ukrainian Press - "Media literacy in Civics lessons" - has been largely compiled as counter-propaganda: teachers are taught to resist Russian media propaganda (Media Literacy..., 2016: 56-60). In particular, in this manual, in our opinion, it is cynically asserted that "the theme of World War II is deliberately politicized today and is used with a manipulative goal to split Ukrainian society. This is dangerous, because often people, who use the Soviet concept of historical memory of the WWII, believe that the Ukrainian state is building the different history, where the heroes are those whom they have always considered enemies. The mythology of World War II is now actively used by Russian propaganda, attempting to discredit Ukraine, declaring a pro-European course and attempts to go beyond the Soviet and post-Soviet mentality and ideology" (Media Literacy..., 2016: 133).

In fact, at the present time the Ukrainian regime is trying to create the different history, claiming heroes those who earlier (in the USSR) were considered enemies. Hence dozens of monuments to the "heroes" of the so-called Ukrainian Insurgent Army (UPA) - nationalists, most of whom served the Hitler regime, especially in 1941-1942. Biography of one of the leaders of Ukrainian nationalists - R.I. Shukhevych (1907-1950) is a striking example: in 1941-1942, he, together with thousands of Ukrainian nationalists, served in the Nazi army (Lisenko, 2008: 27).

Of course, thousands of Russians served in Hitler's armies, and the commander of the socalled Russian Liberation Army (ROA), General A.A. Vlasov (1901-1946) was no better than R.I. Shukhevych and his associates. But in Russia, the Vlasov activities have been officially condemned, they have never been considered, are not considered, and, hopefully, they will never be considered heroes; whereas today in Ukraine 35 streets are named after Shukhevych, 11 monuments are erected (Shukhevych, Wikipedia). Dozens of monuments are installed in Ukraine in honor of many other Ukrainian nationalists who collaborated with the Nazis ... Can this be called the "pro-European course" of the Ukrainian government?

Even further, regarding lies and manipulations, in our view, goes a similar manual for teachers "Media Literacy and Critical Thinking in Social Studies", also developed and published by the Academy of the Ukrainian Press. Some of its units have clearly anti-Russian orientation (Media Literacy..., 2016: 106-109).

To address the issue in more detail, we'll look at the sample paragraph of this manual, where its authors assert that "working with the images of Stepan Bandera, we saw in practice how the negative image of one of the symbols of the Ukrainian liberation struggle is being formed and the corresponding myths are emerging. They can be decoded only through critical thinking and a comprehensive analysis of the authentic sources. ... Soviet, and then Russian propaganda from the second half of the 1940 s has interpreted the personality of Stepan Bandera as a Nazis' (fascist's) accomplice. In accordance with this, since 1946, the supporters of the Ukrainian statehood began to be labeled by Soviet propaganda as fascists-Bandera" (Media Literacy..., 2016: 13-14).

Following the guidance of the textbook's "Media Literacy and Critical Thinking in Social Science Lessons" authors (2016); using critical thinking, let's turn to the analysis of original primary sources. Supporters of S.A. Bandera (1909-1959) and the so-called Act of the Proclamation of the Ukrainian State (1941), usually as the main argument, appeal to the fact that after the signing and promulgation of this act on June 30, 1941, S.A. Bandera was arrested by the Nazis and sent to a concentration camp, he was released only in 1944, and therefore did not take part in military operations (Marchenko, 2018, etc.).

In fact, the Nazi leadership did not like the actions of S.A. Bandera's associates related to the proclamation of the so-called "independence" of Ukraine. But if one carefully reads the original text of the Act of the Proclamation of the Ukrainian State (1941), one can easily find that S.A. Bandera 
and his supporters did not in the least assume the true Ukrainian "independence", arguing that "...3. The newly formed Ukrainian state will work closely with the National-Socialist Greater Germany, under the leadership of its leader Adolf Hitler which is forming a new order in Europe and the world and is helping the Ukrainian People to free itself from Moscovite occupation" (Act ..., 1941: 1) (to be substantive, the full text of The Act of Proclamation of Ukrainian Statehood (1941) is attached in the annex). I wonder if the full text is provided by Ukrainian teachers to their students and whether they are ashamed to acknowledge the Ukrainian nationalists wanted to live according to Nazis laws, and, consequently, to accept and welcome all their actions (for example, Holocaust)?

The prominent Ukrainian theorist of media and information wars G.G. Pocheptsov pertinently identifies the following parameters of the intensity, and hence the artificiality of propaganda campaigns:

- "a simultaneous sudden beginning and a similarly simultaneous completion of the entire campaign or its individual stages,

- the use of all genres, not just news, for example ... talk shows,

- a rigid selection of representatives of the single viewpoint of view on screen, society),

- involvement of all sorts of communicative "allies" (in other countries, in different strata of

- preparation of strategic communication projects in the form of documentary and feature films, as well as a series of books on this subject,

- linking schools, which are the tool of the Ministry of Education, which, as is known, in modern societies performs the functions of the Ministry of Propaganda,

- the use of the descriptive language, which was previously banned,

- a sharp overstatement of the emotional tone of such messages" (Pocheptsov, 2015).

All the above is accurate, but it should be deplored that some Ukrainian media educators (Gumenyuk, Potapova, 2015; Media Literacy..., 2016, etc.) understand this kind of mechanisms, unfortunately, is a very biased way, applying it solely to Russian propaganda, excluding Ukrainian and Western one.

It should be noted that to his credit, G.G. Pocheptsov precisely sees the omnitude of media propaganda laws, because "intensive changes in the physical space require the same intensive changes in the information space (for example, the volume of communications on this subject is dramatically increasing both in public and in non-public spheres) and virtual space (for example, "fraternal peoples" from Soviet rhetoric belong to the virtual level, because they describe sacred values). Ukraine in return also uses a virtual reference to the "imperial ambitions of Russia" ... the opposite sides see, as a rule, absolutely different realities, reasonable for each side involved" (Pocheptsov, 2015).

Moving on to the modern practices of introducing media education in Ukraine, in recent years, it has been implemented in ten Ukrainian regions. In doing so, $84 \%$ of the 90 interviewed teachers, currently teaching media literacy, were trained in formal media education courses, $16 \%$ were self taught. In secondary schools the introduction of media education takes place in various forms, as a result of which various aspects are enhanced and developed - from the psychological (including the development of critical thinking) to the practical (the creation of media products). Ukrainian teachers see the future of media education in including it in school curricula and in the development of integrated learning (Implementation..., 2015: 6-7; Concept ..., 2010; Naydyonova, 2013: 63-79).

With the onset of an active confrontation between Ukraine and Russia, the development of media education in Ukraine generated serious interest among American (and European) politicians. In this regard, it is very significant that when the 6th International Scientific and Methodological Conference on April 20th and 21st in Kyiv, organized by Internews and the Academy of the Ukrainian Press, was held, it was opened by M. Yovanovitch, USA's Ambassador Extraordinary and Plenipotentiary to Ukraine (Dorosh, 2018). It is clear that in the context of sanctions directed against the Russian Federation, American politicians are very interested in seeing media education in Ukraine develop with a propaganda bias, with a tangible flavor of antiRussian orientation. 
Countries with an average level of mass media education development

Moldova

Moldova joined the process of mass media education relatively recently and, without its own financial resources for the development of media education, immediately found itself under strong influence of Western projects in this field (Lang, 2015; English for Media Literacy Project in Moldova, 2017; International recognition for Moldovan librarians as Media Literacy Trainers, 2018, etc.). In April 2014, the Independent Journalism Center (IJC), in partnership with Radio Free Europe launched the project "Media Literacy for Young Moldovan People" (Suryapin, 2016). The project "Promoting media literacy among Moldovan citizens" was implemented by the IJC between March 2013 and April 2014 with the financial support of the United States Embassy in Moldova.

The main thrust of the development of mass media education in Moldova, as many Western politicians want to see it, is best explained by V. Bucataru in the following recommendations: "Publicly address topics such as critical media consumption, fake news, propaganda and disinformation through examples that relate to daily life and take into account professional, religious, ethnic, and linguistic background; ... Set up institutional partnerships that engage with the strategic communication centers of the EU and NATO, and thus interact in platforms that address information war on a multinational levell" (Bucataru, 2018: 5-6).

One has to admit - it's an unexpected twist in media education recommendations for the development of democracy - to establish a partnership with NATO. Clearly, Moldovan media education is directed towards the ideological platform. Moreover, there is a clear instruction, who/what it is necessary to "media educate", the population against: "Not a member of EU or NATO but still at their frontier, Moldova remains ever vulnerable to foreign influence. Russia will continue to target the country and attempt to deepen societal divisions by, among other means, undermining institutional trust. For Russia, this approach highlights both frustration over its lost sphere of influence and intentions to be seen as a strong actor in the regional and international arena. ... Russian TV channels in Moldova have become a means of delivery for fake narratives and propaganda, a highly controlled and centralized "golden pipeline." (Bucataru, 2018).

\section{Armenia}

A lot of academic publications on media education are being currently published in Armenia (Kazdanyan, Chilingaryan, 2016; Muradyan, Manukyan, 2017, etc.). The main media education resource of Armenia is the Media Education Center (www.mediaeducation.am); its organizers develop various teaching materials and conduct events (including conferences) that promote the development of media competence of the population. Media programs of the Yerevan educational complex "Mkhitar Sebastatsi" are moving in the same direction.

The activity of the Media Initiatives Center (www.mediainitiatives.am), which develops media literacy in Armenia, should also be noted. The Media Initiative Center develops lesson plans, recommendations and educational games for schools, and works closely with the Ministry of Education to integrate media literacy into the school curriculum (in particular, the Ministry of Education of Armenia approved the Media Literacy Teacher's Manual prepared by this center). The Media Initiative Center also collaborates with libraries and museums, using an integrated approach to implement the UNESCO-promoted concept of media and information literacy (MIG) (Grizzle, 2017). The project of the "Media Initiatives Center", entitled "Educating the public about media literacy," is of interest. Within the framework of this project, about twenty videos about the role and functions of media in modern society were produced (Suryapin, 2016). In 2017, the Armenian Media Initiatives Center together with the Media Support Center (Kyrgyzstan) received the Media and Information Literacy (MIL) Award from the Global Alliance for Partnership on Media and Information Literacy (GAPMIL).

However, recently the development of media education in Armenia is sometimes associated with an anti-Russian attitude. For example, G. Vardanyan is convinced that "the pro-Russian position is the result of intensive and effective Russian propaganda. Russian media in Armenia, in particular TV channels, are broadcast in free access. ... What can be done to counter propaganda in general and Russian propaganda in particular? One of the recipes is media literacy. Starting from school one needs to teach children critical thinking and correct media consumption. This will reduce the chances of the propaganda's impact. Fact checking is part of 
media literacy. And if you repeatedly imagine how a Russian propaganda machine is lying, it will help people to distinguish between the truth, a half-truth and lies" (Vardanyan, 2017).

\section{Belarus}

The development of media education in Belarus in the 1990s - the beginning of the XXI century in many ways resembled similar processes in Ukraine. For a long time the mediaeducational articles of descriptive nature prevailed in Belarus, as a rule, they briefly retell the content of the research of foreign scientists, and Russian researchers on media education (Dubrovskaya, 2013: 91-95; Kovbasa, 2013: 39-40; Kurachenko, 2012: 60-62; Pugach, 2011: 38-39; Sharko, 2012: 137-145; Spirina, 2013: 28; Zhilinskaya, 2008).

However, in the Republic of Belarus "in recent years there has been a significant increase in interest in media education - both in the academic community and in the pedagogical environment. ... The most active theoretical development of problems of media education is carried out in Belarus State University, Grodno State University, Mogilev Institute of the Ministry of Internal Affairs, and some other universities of the country. In the school curricula, as a separate academic subject, media education is not included, its implementation in the system of secondary and higher education in Belarus is carried out through the introduction of media components in the academic disciplines" (Venidiktov, 2015: 192-193). One can agree that "in connection with the theoretical and methodological underdevelopment of issues of media education in Belarus, research in this area is relevant" (Kovbasa, 2013: 40).

In 2016, the first textbook for educators was published in Belarus, "Media Education in a Modern School: Developing Media Literacy of Students" (Media Education..., 2016), which contains units related to the role of media in the modern world, types, genres and language of media, analysis of media texts, media manipulation, the development of critical thinking, the tasks of media education, media competence, media education, integrated into various school disciplines, extra-curricular activities of children and youth, in the work of film clubs, etc.

The authors are convinced that this textbook "has a number of peculiarities that, without exaggeration, make it a unique publication: it is innovative in form and content, since manuals for teachers on the problem of media education of students in our country have not been published; the texts are structured in such a way that, in addition to highlighting the relevant aspects of the topic of media education, readers are invited to complete the tasks themselves, answer questions and, thus, experience media literacy development or suggest these assignments to their students; the book contains many examples, ready-made scenarios for classes" (Media Education..., 2016: 10). True, it's a little embarrassing that sometimes the Internet links offered to readers of this manual lead ... to the anti-Russian site StopFake: Struggle against fake information about events in Ukraine (Media Education..., 2016: 240). I would not want to think that Belarus media educators will take up the ideological trend of Ukrainian media pedagogy of recent years, but the trend in itself is rather alarming ...

It should be noted that in the same year in Belarus, a review of this training manual was published, stating that "all the chapters included in its structure have a single basis: an orientation toward the formation of liberal thinking, the essence of which is the orientation towards a single individual autonomy of a student and anthropocentrism (a person is the measure of everything). It is no coincidence that the goal and product of media education in the peer-reviewed publication is an independent subject capable of resisting the temptations of the media world at the expense of a personal resource and creatively using its potential for cultural, social and personal development. This concept can become the basis for the development of the national concept of media education, which is argued as necessary by one of the authors (article by Alla Lozitskaya)" (Polonnikov, 2016: 46).

It is to be hoped that the national concept of media education in Belarus will be balanced and comprehensive, since there are good reasons stated in recent articles of Belarus media educators (Dubrovskaya, 2013: 91-95; Gubarevich, 2017: 19-32; Kurachenko, 2012: 60-62; Venidiktov, 2015: 190-196; Zhilinskaya, 2008).

\section{Kazakhstan}

Back in 2010, "the only school of journalism in Kazakhstan was in Kazakh National University (KazNU) named after al-Farabi, the largest university in the country. It is this faculty that develops state curriculum standards, that is, it actually forms the standards of media 
education. Other universities that train journalists have only departments and chairs"(Jalilov, 2010: 111). It has been repeatedly noted that there is a need in Kazakhstan for organizing media education trainings and seminars for teachers, since most of them "have never worked in the media and prepare their lectures based on textbooks and books published in the Soviet Union" (Kulinsky, 2010: 159).

As in Belarus, the process of mass media education in Kazakhstan began with the adaptation of Russian experience, but then, thanks to the efforts of the research group headed by L.S. Akhmetova, quickly became equipped with an analysis of foreign media education theories (Akhmetova, Verevkin, Lifanova, 2017). In 2014, L.S. Akhmetova noted that "the issues of media education in Kazakhstan today are rather debatable among researchers, bloggers, participants of social networks, and general publich advanced in the field of new technologies. Everyone understands that this is necessary. However, not enough attention is paid to such issues yet"(Akhmetova, 2014: 37). Over the past four years, the situation has changed for the better media education literature is being published more and more often (Akhmetova, 2011; 2012; 2013; 2014; 2016; Akhmetova, Verevkin, Lifanova, 2015; 2017; Akhmetova, Verevkin, Lifanova, Shorokhov, 2013; Akhmetova, Shorokhov, Niyazgulova, 2015).

L.S. Akhmetova's team published collective monographs "Media Education in Kazakhstan" (2013), "Media Education and Media Literacy: Theory, Methodology, Practice" (2015). Having received a grant from the Ministry of Education and Science of Kazakhstan on the theme "Development of media and information literacy of the youth in the context of ensuring national security and the implementation of the State Program" Informational Kazakhstan - 2020 ", they produced another significant work - "Media and Information Literacy: Conceptual and Methodological Foundations" (2017), which took into account the current UNESCO recommendations on the synthesis of information and media competence of the individual.

And although media education has not entered Kazakhstan schools on a massive scale yet, it can be hoped that in the coming years Kazakhstan will be able successfully implement media education programs at different levels.

Countries with a low level of mass media education

Media education in Uzbekistan for a long time was in the phase of protracted formation (Abdurakhmanov, Beknazarova, 2011: 20-24; Beknazarova, 2011; Ismailova, 2016: 121-126). The textbook "Uzbekistan on the path to the development of media education" (Mamatova, Sulaimanova, 2015) serves a vivid example, because, contrary to its title, it contains almost no information about what is actually going on in the field in Uzbekistan. However, the training manual contains a brief adapted rendering of UNESCO's recommendations on the development of media and information literacy, and it is a progressive step.

Moreover, "in 2015-2017 on the initiative of the UNESCO Office in Uzbekistan and the National Library of Uzbekistan named after A. Navoi, the project "Development of information culture and media literacy of specialists of information and library institutions of Uzbekistan in the period of deepening reforms in the information and library sphere" was realized. The goal of the project is to train specialists of information and library institutions of Uzbekistan in the promotion of the ideas of UNESCO and IFLA on media and information literacy through the training course "Fundamentals of the Information Culture of a School Student", as well as to adapt these training materials in order to facilitate their perception by schoolchildren in Uzbekistan" (Gendina, 2017: 37).

As a result, the authors of the project prepared a number of useful recommendations on the development of media and information literacy in Uzbekistan: first, "to compare the UNESCO curriculum with the existing national curricula on information and / or media literacy, to determine the contents of the missing information and / or media components. Then add the missing component (media or information), thereby ensuring a balance between media and information competencies. Further, it is necessary to analyze the definitions borrowed from the UNESCO curriculum in accordance with the terms and concepts accepted in the country and, if necessary, to supplement the composition of the glossary. In addition, the information and media resources recommended in the UNESCO curriculum should be selected and replaced with appropriate national information and media resources, and then a list of literature in the national language (s) should be compiled. After that, it is required to analyze the educational text with the help of ethnomarkers and replace the identified precedent phenomena by analogues 
corresponding to the realities of the country (geographical, literary, folklore and historical objects, political associations and organizations, laws, etc.)" (Gendina, 2017: 41).

Active processes that promote the development of mass media education have begun in recent years in Kyrgyzstan, where "the existing activities to improve the level of media literacy as a skill and the development of media literacy as a science are in a rudimentary stage" (Report..., 2018: 94). These conclusions were drawn based on the results of a study assessing the levels of media literacy of the population (over 16 years) in the Kyrgyz Republic. It was held in September November, 2017, 1200 urban and rural respondents from seven regions were interviewed (Report ..., 2018: 11).

The main lever for the development of media education in Kyrgyzstan is the non-profit Foundation "Media Support Center", established in 2002. The first project to develop media and information literacy in Kyrgyzstan was launched by the Foundation in 2012 in partnership with IREX Europe and the Deutsche Welle Academy. Through the efforts of the Media Support Center Foundation in Kyrgyzstan, 25 schools have already piloted the media literacy lessons developed by the Foundation in cooperation with the Kyrgyz Ministry of Education and Science and the Kyrgyz Academy of Education. In Kyrgyzstan such an experiment is being conducted for the first time. The project has already covered about three hundred children in Bishkek and its suburbs. ... The first thing that the teachers teach the course is not to take any information for granted. Regardless of where it publicized - everything needs to be checked by other sources. Those who have taken the course say that they watch daily news reports with a different attitude now" (Begalieva, 2017).

Most recently, in 2018, Kyrgyzstan published the first textbook for teachers on media and information literacy (Imankulov et al., 2018), which, seems to provide significant help in developing the media competence of both the teachers and their students.

Unfortunately, the development of media education in Azerbaijan, Tajikistan and Turkmenistan still lags far behind Kyrgyzstan and Uzbekistan.

In general, modern development of media literacy in Kazakhstan, Kyrgyzstan, Tajikistan, Turkmenistan and Uzbekistan is supervised by Western organizations IREX Europe and Albany Associates. In 2018, with the support of the British Embassy in Kazakhstan and the British Embassy in Kyrgyzstan, in the framework of IREX Europe, a series of teaching aids in Russian was published (which remains the language of cross-ethnical communication of the CIS countries). Note that "Media literacy: a practical textbook for higher education institutions on media and information literacy" (Sturkhezky, 2018) and "Media literacy. A practical manual for librarians" (Kozitska, 2018), unlike many of the Ukrainian analogues of recent years, are sustained in a politically neutral manner. The first of them (Sturkhezky, 2018: 97-101; 133-135) cites the research of our scientific school, and contains links to the Internet resource "Information Literacy and Media Education for All" (www.mediagram.ru) also created with participation of Taganrog media education research team (Russia).

Unfortunately, the publication "Propaganda, deepening the abyss in mutual understanding. Monitoring of the media of the Eastern Partnership countries and Russia" lacks the balanced representation of views (Propaganda ..., 2016). Media monitoring of the six countries of the Eastern Partnership and Russia was held from June 6 to July 3, 2016 within the framework of the project "Joint Efforts and Professional Knowledge to Counter the Propaganda", supported by the Czech Ministry of Foreign Affairs and the Secretariat of the Eastern Partnership Civil Society Forum and implemented by the Yerevan Press Club in partnership with Internews Ukraine, MEMO 98 (Slovakia), Independent Journalism Center (Moldova), the Charter of Journalistic Ethics of Georgia, the Belarusian Association of Journalists and the Azerbaijani expert group" (Propaganda ..., 2016: 4). Meanwhile, "this study was focused on monitoring and detecting the potential impact of, so to speak, "migrating" propaganda messages (stereotypes, narratives), often falling into the information space, including media of the Eastern Partnership countries, specifically of Russian federal channels or under the influence of their content" (Propaganda ..., 2016: 4).

Thus, the authors of the study seem to have "forgotten" that propaganda is not a one-way street, and if we are to investigate the mechanisms of propaganda, then we should consider examples of propaganda produced by different countries, rather than consider that propaganda exists only in Russia, and in other countries (for example, the United States, Britain, Germany, 
France) everything is so democratic that propaganda and "migrating ideological stereotypes" are out of the question.

In this context, it is very significant that in 2018 the US authorities, disturbed by the "excessive influence of Russian media on public opinion" in the countries of Central Asia, "allocated \$ 15 million to support independent journalists and raise the level of media literacy in this region" (US ..., 2018).

\section{Results}

Comparative analysis and synthesis of goals and objectives, key concepts, the main stages of historical development, structure, content, models of mass media education in the CIS countries allows to develop the following scheme.

Goals and objectives of mass media education in CIS countries

The general goal of mass media education for all CIS countries is to develop and improve the level of media literacy / media competence of the population (that is, culture of communication with media, creative, communicative abilities, analytical thinking, the ability to create, disseminate, interpret, analyze and evaluate the role and functions of media in society, media texts of different types and genres).

Mass media education objectives:

- practical-creative (training in the ability to search, create and distribute media texts of various kinds and genres while respecting the humanistic focus and ethical correctness of these messages);

- analytical (training the skills of qualified analysis and evaluation of the role and functions of media in the society, media texts of various types and genres);

Peculiarity of tasks:

- in some CIS countries (Ukraine, Moldova), these tasks are increasingly associated with the opposition to Russian media influence.

General key theoretical concepts of mass media education in the CIS countries:

- practical (focused on teaching hands-on skills of work with media technology with the subsequent creation and dissemination of media texts);

- development of critical thinking about the role and functions of media culture in society and media texts of different types and genres;

- protectionist (typical for the synthesis of media education and religion);

- aesthetic (oriented to bring up a high aesthetic taste on the material of the most highquality works of media culture);

- sociocultural and cultural studies (analysis of the role of media in society and media texts in a broad socio-cultural context).

A number of theoretical concepts (semiotic, ecological, ethical, etc.) have little effect on the development of media education in the CIS countries.

Peculiarities: in Ukraine (an associated member of the CIS since 1993), in recent years, the ideological theory of media education has been favoured, in which critical thinking is developed through detecting fake media information, in particular, in the news (Gumenyuk, Potapova, 2015; Media Literacy..., 2016; Training..., 2015). Starting from 2014, the development of media education in Ukraine increasingly goes hand in hand with anti-Russian propaganda (Gumenyuk, Potapova, 2015; Dorosh, 2014; Emets-Dobronosova, 2014; Koropatnik, 2015; Media Literacy..., 2016; Training ..., 2015; Cherepovska, 2015, etc.).

The main stages of the historical development of mass media education in the CIS countries

in the 1990s: countries);

- deprivation of the state support during the years of "perestroika" (typical for all CIS

- gradual departure from the popular in the Soviet period ideological and aesthetic approaches of media education, exploration of the Western approaches (culturological, development of critical thinking, etc.) (typical for Russia, Ukraine and Belarus);

- presence of only weak foci of media education in a number of CIS countries: typical for Azerbaijan, Georgia (until 18.08.2009 Georgia was part of the CIS), Tajikistan, Turkmenistan (Turmenistan is associated member of the CIS) and Uzbekistan; 
Russia);

- attempts of private business to support the media education movement (typical only for

- intensive development of academic research in the field of media education (at this stage it is typical mainly for the Russian Federation);

XXI Century:

- recognition of the importance of media education at the state level (typical for Ukraine, where in 2011-2018 a large-scale experimental introduction of media education in dozens of secondary schools began, and to a lesser extent for Russia, where on November 17, 2008 the Government approved the Concept of Long-Term Social and Economic Development of the Russian Federation for the period until 2020, where in the section on information and communication technologies the need for media education is declared; in 2013 the Ministry of Education and Science of the Russian Federation supported the idea of film education as an elective in secondary schools);

- intensive use of new Internet technologies for the development of media education (primarily in Russia, Ukraine, Belarus, Armenia, Kazakhstan and Kyrgyzstan);

- launching new university majors/minors related to media education (Russia, Ukraine);

- convening a series of international and regional conferences (incl. UNESCO sponsored) on media education (Russia, Ukraine, Belarus, Armenia);

- organizing a series of international and regional schools, training seminars, courses on media education (primarily in Russia, Ukraine, Belarus, Armenia, Kazakhstan and Kyrgyzstan);

- continuation of the intensive development of research in the field of media education, carried out in many cases with the support of Russian science foundations and foreign funds (for the Russian Federation) or only foreign funds (typical for Ukraine, Moldova, Kyrgyzstan);

- gradual integration of media education programs in a number of CIS countries (typical for Azerbaijan, Armenia, Georgia (until 18.08.2009 Georgia was part of the CIS), Kazakhstan, Kyrgyzstan, Moldova, Tajikistan, Turkmenistan and Uzbekistan).

Structure and content of models of mass media education in the CIS countries

Conceptual basis: synthesis of the theory of development of critical thinking, practical, and sociocultural theories of media education.

Aim: development of media literacy / competence of the individual.

Objectives: development of the following skills: practical, creative, analytical.

Methods of media competence's development: verbal, visual, explanatory-illustrative, problem- based research.

The main units of the contents of the media education program (the availability of a particular unit depends on the age and professional status of the audience): the place and role, functions of media and media education in modern society, types and genres, media languages; basic terms, concepts related to media culture; historical stages of development of media culture in the world; analysis and evaluation of the functioning of media and media texts of different types and genres in the socio-cultural and ideological contexts; technologies of creation and distribution of media texts of various kinds and genres.

Areas of application: schools, secondary special educational institutions, higher education institutions, professional development courses, additional education institutions and leisure centers; distant media education of various categories of the population; independent (continuous) media education, for example, through Internet sources.

Anyway, all modern models of media education in the CIS countries (with all the diversity of age and professional entire population groups) contain diagnostic, content-targeted and effective components (Akhmetova, 2011; 2012; 2014; 2016; Baranov, 2002; Beknazarova, 2011; Bondarenko, 2009; Fateeva, 2007; Fedorov, 2001; 2007; Gendina, 2017; Gumenyuk, Potapova, 2015; Hilko, 2007; Ivanov, Ivanova, 2013; Kirillova, 2012; Korkonosenko, 2004; Korochensky, 2005; Koropatnik, 2015; Naidyonova, 2013; Onkovych, 2009; Sakhnevich, 2010; Sharikov, 2012; Spichkin, 1999; Vartanova, Zasursky, 2003; Venidiktov, 2015; 2017; Zaznobina, 1998; Zhurin, 2009, etc.), which take into account the best Western media education practices (Bazalgette, 1989; Bowker, 1991; Buckingham, 2000; 2003; Debray, 1991; Gonnet, 2001; Hart, 1991; 1997; Masterman, 1985; 1997; Potter, 2016; Scheibe, Rogow, 2012; Silverblatt, 2001; 2014). 


\section{Conclusion}

It is necessary to agree that "the question of the possibility of developing cross ethnic media education systems that reflect the needs of integration groups in the global media discourse and which can withstand external information threats is quite debatable. The search for answers will inevitably affect: a) the educational environment in which media literacy courses should be introduced (at various levels of instruction), developed with the account of international information interests; b) the media sphere, which includes the contents of all types of media (both national and allied) and carrying out a spontaneous impact on the audience's citizenship; c) political reality, predetermining the attitude of citizens to the information provided to the media and, on the other hand, experiencing the consequences of the audience's information choice; d) institutions of civil society (local, national and transnational), whose viability largely depends on the sustainability of the information sphere; e) ideological climate in integrable societies" (Venidiktov, 2015: 194). Herewith, we believe that the CIS countries should not build the development of mass media education of the population based on confrontation and ideological propaganda. All thematical blocks of media education programs should evenly give the audience an idea that there are no ideal democratic states in the world with ideally objective mass media. That is why the basis of media education activity must be sociocultural concepts (including, of course, analytical and practical components) rather than ideological ones that will allow the audience to comprehensively master the ambiguous world of media culture.

\section{Acknowledgements}

The reported study was funded by Russian Foundation for Basic Research (RFBR) according to the research project № 18-013-00022 "Mass Media Education in Commonwealth of Independent States - CIS (1992-2020)".

\section{References}

Abdurakhmanov, 2011 - Abdurakhmanov, K.P., Beknazarova, S.S. (2011). From the History of the Development of Media Education in Uzbekistan. Media Education, № 2: 20-24.

Afanasjev, 2010 - Afanasjev, D.M. (2010). Development of young people's media literacy: Slovak Republic and Ukraine: Comparative analysis. Sociology of the future. № 1: 41-49.

Akhmetova, 2011 - Akhmetova, L.S. (2011). Gender, Media Literacy and Media Education: Problems and Prospects. Gender Aspects of Social Modernization of Society: Proceedings of the international conference. Almaty: 287-291.

Akhmetova, 2012 - Akhmetova, L.S. (2012). Media literacy and media education in the context of national security protection. Narrow problems of media legislation of the Republic of Kazakhstan. Almaty: 29-32.

Akhemetova, 2013 - Akhmetova, L.S. (2013). Media Education and Media Security in Kazakhstan: Problems and Prospects. Vestnik of Chelyabinsk University. № 21 (312). URL: http://cyberleninka.ru/article/n/mediaobrazovanie-i-mediabezopasnost-v-kazahstane-problemyi-perspektivy

Akhmetova et al, 2013 - Akhmetova, L, Verevkin, A., Lifanova, T. (2013). Media Education In the Context of Development of Kazakhstan Journalism. World Applied Sciences Journal. № 25 (11): 1624-1629.

Akhemetova et al, 2013 - Akhmetova, L.S., Verevkin, A.V, Lifanova, T.Y., Shorokhov, D.P. (2013). Media education in Kazakhstan. Almaty: Kazakh University, 254 p.

Akhemetova, 2014 - Akhmetova, L.S. (2014). Media education in Kazakhstan. International Journal of applied and fundamental research. № 3: 37-38.

Akhemetova, 2015 - Akhmetova, L.S, Verevkin A.V, Lifanova T.Y. (2015). Media education and media literacy: theory, methodology, practice. Almaty: Kazakh University, $156 \mathrm{p}$.

Akhemetova et al, 2015 - Akhmetova, L.S., Shorokhov, D.P., Niyazgulova, A. (2015). MIL: media and information literacy. Almaty, $36 \mathrm{p}$.

Akhemetova, 2016 - Akhmetova, L.S. (2016). Media education in Kazakhstan: problems and prospects. Media education: experience and perspectives. Vol. 1. Voronezh: 12-15. URL: http://jour.vsu.ru/editions/thesis/o5_16_mediaobr.pdf

Akhemetova, 2017 - Akhmetova, L.S., Verevkin, A.V, Lifanova, T.Y. (2017). Media and information literacy: conceptual and methodological grounds. Almaty: Kazakh University, 48 p. 
Atrihalova, 2010 - Atrihalova, E.V., Ksenofontov, I.V. (2010). Using the potential of films of a spiritual and moral focus at modern school. Kaluga, $64 \mathrm{p}$.

Bakirov, 2013 - Bakirov, V.S., Starodubtseva, L.V. (2013). Creative model of media literacy: Experiment of the Karazinsky University. Collection of the articles of the methodological seminar "Media education in Ukraine: scientific reflexion of theories, practitices, and perspectives". Kiev: National Academy of Pedagogical Sciences of Ukraine: 45-62.

Balyk, 2012 - Balyk, N. (2012). Development of media literacy as a key competence in modern pedagogical education. Edukacja humanistyczna. № 2 (27): 171-177.

Baranov, 1979 - Baranov, O.A. (1979). Screen Becomes a Friend. Moscow: Prosveshchenie, $96 \mathrm{p}$.

Baranov, 2002 - Baranov, O.A. (2002). Media education in school and university. Tver.

Barishpolets et al, 2009 - Barishpolets, O.T., Naidonova, L.A. et al. (2009). Media culture of the person: socio-psychological approach. Kiev: Millenium, $440 \mathrm{p}$.

Barishpolets, 2008 - Barishpolets, O.T. (2008). Media education: foreign experience. Social Psychology. № 3: 162-170.

Basics of media literacy - Basics of media literacy: teaching manual for 8(9) grades (2014). Kiev, 190 p.

Bazalgette, 1989 - Bazalgette, C. (1989). Primary Media Education: A Curriculum Statement. London: BFI.

Bazalgette, 1995 - Bazalgette, C. (1995). Key aspects of media education. Report at the Russian-British seminar on media education. Moscow, $51 \mathrm{p}$.

Begalivea, 2017 - Begalieva, Zh. (2017). Schools of Kyrgyzstan introduced the lessons of media literacy: they teach to distinguish truth from lies in the media. Nastoyascheje vremya. URL: https://www.currenttime.tv/a/28450935.html

Beknazarova, 2011 - Beknazarova, S.S. (2011). Comparative analysis of the introduction of elements of media education in the learning process. Media education. № 3: 75-83.

Bondarenko, 2009 - Bondarenko, E.A. (2009). Media formation in the formation of a modern educational environment. In: Educational technologies of the XXI century. Moscow. Russian Academy of Education: 51-57.

Bondur, 2008 - Bondur, Y.V. (2008). Pedagogical conditions of artistic education of senior pupils by means of media culture. Academic Herald of Mikolaivsky University. Issue 21. Vol.1: 33-36.

Bostonova, 2010 - Bostonova, P. (2010). The state and prospects of journalistic education in Kyrgyzstan. Journalists' education - improving the quality of education and new technologies. Vienna: OSCE: 143-151.

Bowker, 1991 - Bowker, J. (Ed.) (1991). Secondary Media Education: A Curriculum Statement. London: BFI.

Bucataru, 2018 - Bucataru, V. (2018). Media Literacy and The Challenge of Fake News. Media Forward. N 1. URL: https://freedomhouse.org/sites/default/files/o1-Fake_News-EN.pdf

Buckingham, 2000 - Buckingham, D. (2000). The Making of Citizens. London - New York: Routledge, $235 \mathrm{p}$.

Buckingham, 2003 - Buckingham, D. (2003). Media Education: Literacy, Learning and Contemporary Culture. Cambridge, UK: Polity Press, 219 p.

Burim, 2012 - Burim, O.V. (2012). Media education - the basis for the formation of a personality culture and a means of protecting youth from the influence of negative media content. Pedagogy of higher and secondary schools. Issue 35: 155-162.

Chelysheva, 2008 - Chelysheva, I.V. (2008). Media education for parents: mastering family media literacy. Taganrog, $184 \mathrm{p}$.

Chemeris, 2006 - Chemeris I.M. (2006). Media education abroad: the theory of media education and a short history of development. Higher Education of Ukraine. № 3: 104-108.

Chemeris, 2012 - Chemeris, I.M. (2012). Media education in the initial educational process: foreign experience. Bulletin of the Cherkasy University. No. 37 (250): 124-130.

Chemeris, 2013 - Chemeris, I.M. (2013). Development of students' media competence (analysis of methodical recommendations). Problems of Modern Pedagogical Education. Vol. 38. Part 2: 215-221.

Cherepovska, 2009 - Cherepovska, N.I. (2009). Media education at School. Social Teacher. № 6: 15-26. 
Cherepovska, 2010 - Cherepovska, N.I. (2010). Media culture and media education for students of secondary school. Visual media culture. Kyiv: Schkolnyi Svit, 128 p.

Cherepovska, 2015 - Cherepovska, N.I. (2015). Media education in educating young people's patriotism in the information day. Collected papers of the Third International Scientific and Methodological Conference "Practical Media Literacy: International Experience and Ukrainian Perspectives". Kyiv: Free Press Center, Academy of Ukrainian Press: 59-67.

Collection of articles, 2013 - Collection of articles (2013). Methodological seminar "Media education in Ukraine: scientific reflection of challenges, practices, perspectives". Kyiv: National Academy of Pedagogical Sciences of Ukraine, 741 p.

Collection of articles, 2015 - Collection of articles (2015). The 3rd international scientific methodological conference "Practical media education: international and Ukranian prospects". Kiev: Center Vilnoi Presi, Academy of Ukranian Press, 407 p.

Collection of articles, 2017 - Collection of articles (2017). The 5th international scientific methodological conference "Practical media education: international and Ukranian prospects". Kiev: Center Vilnoi Presi, Academy of Ukranian Press, 393 p.

Concept, 2010 - Concept of implementation of media education in Ukraine. Institute of social and political psychology of National Academy of Pedagogical Sciences of Ukraine. http://www.ispp.org.ua/news_44.htm

Debray, 1991 - Debray, $R$. (1991). Cours de médiologie générale. Paris: Gallimard, 408 p.

Dorosh, 2014 - Dorosh, M. (2014). War - high time for media education? 15.09.2014. URL: http://osvita.mediasapiens.ua/material/34599

Dorosch, 2018 - Dorosh, M. (2018). How Media Literacy is Developing in Ukraine: Eight Conclusions from Annual Conferences. Media Sapiens. URL: http://ms.detector.media /mediaprosvita/mediaosvita/yak_rozvivaetsya_mediagramotnist_v_ukraini_visim_visnovkiv_zi_ schorichnoi_konferentsii/

Dub, 2002 - Dub, O. (2002). Media education: world practice at the present stage. New ways of communication. № 4-5.

Dubrovskaya, 2013 - Dubrovskaya, O. (2013). Media education in the process of socialization (analysis of the contents of the weekly "Banner of Youth"). Journalism history: lessons and practice of the media. Minsk: Belarus State University: 91-95.

Emets-Dobronosova, 2014 - Emets-Dobronosova, Y. (2014). "Media education" for the Kremlin recipe. URL: https://krytyka.com/ua/community/blogs/mediaosvita-za-kremlivskymretseptom

English for Media Literacy... - English for Media Literacy Project in Moldova, 2017. URL: https://www.onlinelearning.upenn.edu/english-for-media-literacy-project-in-moldova/

European Parliament Resolution... - European Parliament Resolution of 16 December 2008 on media literacy in a digital world (2008/2129(INI)) URL: http://www.europarl.europa.eu /sides/getDoc.do?pubRef=-//EP//TEXT+TA+P6-TA-2008-0598+O+DOC+XML+Vo//EN

Fateeva, 2007 - Fateeva, I.A. (2007). Media education: theoretical basics and implementation experience. Chelyabinsk, $270 \mathrm{p}$.

Fateeva, 2015 - Fateeva, I.A. (2015). Topical issues of media education. Chelyabinsk: Chelyabinsk State University, $129 \mathrm{p}$.

Fedorov, 2001 - Fedorov, A.V. (2001). Media education: history, theory and methods. Rostov: CVVR, $708 \mathrm{p}$.

Fedorov, 2003 - Fedorov, A. (2003). Media Education and Media Literacy: Experts' Opinions. MENTOR. A Media Education Curriculum for Teachers in the Mediterranean. Paris: UNESCO.

Fedorov, 2003 - Fedorov, A.V. (2003). Media education in foreign countries. Taganrog: Kuchma, 283 p.

Fedorov, 2007 - Fedorov, A.V. (2007). Development of media competence and critical thinking of students of a pedagogical university. Moscow: ICO "Information for All", $616 \mathrm{p}$.

Fedorov, 2007 - Fedorov, A.V. (2007). Media Education: sociological surveys. Taganrog: Kuchma Publishing House, $228 \mathrm{p}$.

Fedorov, 2009 - Fedorov, A.V. (2009). Scientific research in the field of media education in Russia (1960-2008). Innovations in Education. №. 3: 53-117. 
Fedorov, Chelysheva, 2002 - Fedorov, A.V., Chelysheva, I.V. (2002). Media Education in Russia: A Brief History of Development. Taganrog: Poznanije, 266 p.

Fedorov, Levitskaya, 2018 - Fedorov, A., Levitskaya, A. (2018). Mass media literacy education in modern Russia Mass media literacy education in modern Russia. Mediaobrazovanie = Media Education. № 2: 6-23.

Fedorov, Novikova, 2005 - Fedorov, A.V., Novikova, A.A. (2005). Media education in the leading Western countries. Taganrog: Kuchma, 270 p.

Fedorov et al, 2014 - Fedorov, A.V., Chelysheva, I.V., Muriukina, E.V., Gorbatkova, O.I., Kovaleva, M.E., Knyazev, A.A. (2014). Mass media education in the USSR and Russia: the main stages. Moscow: ICO "Information for All", $267 \mathrm{p}$.

Fortunatov, 2009 - Fortunatov, A.N. (2009). Interaction of subjects of social communication in media reality. Author's abstract of Ph.D. dissertation. N.Novgorod, 37 p.

Freinet, 1990 - Freinet, C. (1990). Selected pedagogical work. Moscow: Progress.

Freinet, 1996 - Freinet, C. (1996). Anthology of humane pedagogy. Moscow: Publishing House of Shalva Amonashvili, $224 \mathrm{p}$.

Gabor, 2002 - Gabor, N. (2002). Media Education... Media-attack. Lviv: Institute of Ecology and Mass Information, Media Center New Journalism: 49-52.

Gelava , Kurdadze, 2018 - Gelava, S., Kurdadze, D. (2018). Guide on media literacy: how to resist manipulation and false information. Tbilisi, $22 \mathrm{p}$.

Gendina, 2013 - Gendina, N.I. (2013). Information Culture and Media Literacy in Russia. Information Society. № 4: 77.

Gendina, 2017 - Gendina, N.I. (2017). UNESCO Curriculum on Media and Information Literacy for Teachers as an Object of Analysis and Adaptation in Russia and Uzbekistan. Media Education, № 3: 27-44.

Gonnet, 2001 - Gonnet, $J$. (2001). Education aux medias: Les controverses fecondes. Paris: CNDP, Hachette, $144 \mathrm{p}$.

Grizzl, 2017 - Grizzl, E. (2017). Organizations in Armenia and Kyrgyzstan among the laureates of the 2017 Award in the field of media and information literacy. URL: https://ru.unesco.org/news/organizacii-v-armenii-i-kyrgyzstane-v-chisle-laureatov-premii-2017goda-v-oblasti-mediynoy-i

Gubarevich et al, 2017 - Gubarevich, D.I., Karpievich, E.F. (2017). Development of media competence of university teachers. How to develop the media literacy of a student and university teacher: strategies and techniques. Issue 10. Minsk: Belarus State University: 19-32.

Gudilina, 2007 - Gudilina, S.I. (2007). Innovative activity in the field of media education. Educational technologies of the XXI century OT'O7. Moscow: 8-13.

Gumenyuk, 2015 - Gumenyuk, L., Potapova, V. (2015). Practical media education. Manual for librarians. Kiev. URL: http://aup.com.ua/books/mbm

Gurinenko, 2009 - Gurinenko, I.Y. (2009). Media-education as a means of training a specialist in civil defense. Information and telecommunication technologies in modern education: experience, problems, perspectives. Part 1. Lviv: 181-184.

Hart, 1991 - Hart, A. (1991). Understanding the Media: A Practical Guide. London: Routledge, p.13.

Hart, 1997 - Hart, A. (1997). Textual Pleasures and moral Dillemmas: Teaching Media Literacy in England. In: Kubey, R. (Ed.) Media Literacy in the Information Age. New Brunswick (U.S.A.) and London (UK): Transaction Publishers, p. 199-211.

Hilko, 2007 - Hilko, N.F. (2007). Pedagogy of audiovisual creativity in the socio-cultural sphere. Author's abstract of Ph.D. dissertation. Moscow.

Imankulov et al, 2018 - Imankulov, M., Usupbaeva, A., Tekimbaeva, A., Danilova, N., Shturhetsky, S., Kozhobekova, B. (2018). Media and information literacy: resource book for the teacher. Bishkek: Media Support Center, 270 p.

Implementation..., 2015 - Implementation of media education and media literacy in secondary schools of Ukraine. Kiev, 29 p.

International..., 2018 - International recognition for Moldovan librarians as Media Literacy Trainers, 4.05.2018. URL: http://irex-europe.fr/2018/05/04/international-recognition-formoldovan-librarians-as-media-literacy-trainers/ 
Ivanov, 2009-2010 - Ivanov, V.F. (2009-2010). Aspects of mass communication. Kiev: CVP.

Ivanov, 2011 - Ivanov, V., Voloshenyuk, O., Kulchynska, L. (2011). Medua education and media literacy: a brief review. Kiev: 58 p.

Ivanov, 2017 - Ivanov, V., Voloshenyuk, O. (eds.). (2017). Author's classes of leading media teachers. Kiev, 50 p.

Ivanov et al, 2012 - Ivanov, V.F., Shkoba, O.Y. (2012). Media education and media literacy: definition of terms. Information Society. Issue 16: 41-52.

Ivanov et al, 2013 - Ivanov, V.F., Ivanova, T.V. (2013). Media education and media literacy as actual trends in the upbringing of modern youth. Collection of articles of the methodological seminar "Media education in Ukraine: scientific reflection of challenges, practices, perspectives. Kiev: National Academy of Pedagogical Sciences of Ukraine: 25-44.

Ivanov et al, 2016 - Ivanov, V., O.Voloshenyuk, O. (eds.) (2016). Media literacy in social sciences: teachers' manual. Kiev, $253 \mathrm{p}$.

Ivanov et al, 2016 - Ivanov, V., O.Voloshenyuk, O., Mokroguz (eds.) (2016). Media literacy in special disciplines: teachers' manual. Kiev, $201 \mathrm{p}$.

Ivanov , Voloshenyuk, 2012 - Ivanov, V., Voloshenyuk, O. (2012). Media education and media literacy. Kiev: AUP.

Ivanov, Voloshenyuk, 2013 - Ivanov, V., Voloshenyuk, O. (eds.) (2013). Practical media education: authentic lessons. Kiev, 447 p.

Ivanov, Voloshenyuk, 2017 - Ivanov, V., Voloshenyuk, O. (eds.) (2017). Parents, children, and the media: parental mediation. Kiev, $79 \mathrm{p}$.

Izmailova, 2016 - Izmailova, K. (2016). Media Education in Uzbekistan: Trends, Problems, Prospects. Foreign Languages in Uzbekistan. № 6: 121-126.

Jalilov, 2010 - Jalilov, A. (2010). Problems and prospects of media education in Kazakhstan. Journalism education - improvement the quality of education and new technologies. Vienna: OSCE: 107-116.

Kazakov, 2007 - Kazakov, Y.M. (2007). Pedagogical conditions for the use of media education in the process of preparing future teachers: the author's abstract of the Ph.D. thesis. Lugansk, $22 \mathrm{p}$.

Kazakov, 2009 - Kazakov, Y.M. (2009). Contemporary Concepts of Media Education for Students and Students. Psychological and Pedagogical Problems of a Village School: Collection of scientific works of the Uman State Pedagogical University. Issue 29. Uman: Sofiya: 88-94.

Kazdanyan, 2016 - Kazdanyan, S.S., Chilingaryan, L.M. (2016). On the role of modern information technologies in the formation of spiritual and moral values of the younger generation in the sphere of education. Bulletin of Science and Practice. №. 10: 353-357.

Kirillova, 2005 - Kirillova, N.B. (2005). Media culture: from modern to postmodern. Moscow: Academic Project, 448 p.

Kirillova, 2012 - Kirillova, N.B. (2012). Medialogy as the synthesis of sciences. Moscow: Academic Project, 368 p.

Korkonosenko, 2004 - Korkonosenko, S.G. (2004). Teaching journalism. Professional and mass media education. Saint Petersburg: Mikhailov Publishing House, 240 p.

Korochensky, 2003 - Korochensky, A.P. (2003). "The Fifth Power"? Media criticism in the theory and practice of journalism. Rostov, $284 \mathrm{p}$.

Korochensky, 2005 - Korochensky, A.P. (2005). Media education in Russia: not only "external" difficulties and obstacles. Media education: 37-42.

Koropatnik, 2015 - Koropatnik, M. (2015). Features of media education in the context of the "hybrid war" of Russia against Ukraine. Collection of articles of the $3^{\text {rd }}$ international conference "Practical media literacy: international and Ukranian prospective". Kiev: 17-25.

Koropatnik, 2017 - Koropatnik, M. (2017). Problems of the media education of the Population of Ukraine in Crimea and in Donbas in the Context of Informational and Propaganda Aggression of the Russian Federation. Collection of articles of the 5th international conference "Practical media literacy: international and Ukranian prospective". Kiev: 357-372.

Kosyuk, 2005 - Kosyuk, O. (2005). Media literacy ludological aspect of solving the problem. Television and Radio Journalism. Issue 6.

Kovbasa, 2013 - Kovbasa, A.V. (2013). Media education of post graduates: theoretical concepts and modern methodological approaches. Organization of post graduate education in the 
conditions of innovative transformations at the military faculty: materials of the scientific and methodological seminar. (Minsk, October 30, 2012). Minsk: 39-40.

Kovbasko, 2013 - Kovbasko, Y.O. (2013). Publishing activity and achievements of the scientific school "Media Education and Media Competence" of Anton Chekhov Taganrog State Pedagogical Institute. Compilation of articles of the methodological seminar "Media education in Ukraine: scientific reflection of challenges, practices, perspectives". Kiev: National Academy of Pedagogical Sciences of Ukraine: 210-218.

Kulinsky, 2010 - Kulinsky, A. (2010). Why is journalistic education inefficient in Kyrgyzstan? Journalism education - improvement of the quality of education and new technologies. Vienna: OSCE: 153-160.

Kurachenko, 2012 - Kurachenko, A.V. (2012). Development of the information culture of future social educators through the introduction of media education courses. Collection of reports of participants of the 4th open scientific and practical conference "Actual problems of education and training in LS. Vygotsky's heritage". Gomel: Gomel State Pedagogical College: 60-62.

Lang, 2015 - Lang, K. (2016). Media literacy. A practical guide for librarians. Chisinau: AO IREX Moldova, $166 \mathrm{p}$.

Lazutkina, 2015 - Lazutkina, E.V. (2015). Media education of adults in conditions of transformation of modern media environment. Open and distance education: 9-14.

Levitskaya et al, 2016 - Levitskaya, A.A., Fedorov, A.V., Muriukina, E.V. et al. (2016). Synthesis of media education and media criticism in the process of future teachers' education. Rostov-on-Don: Southern Federal University, 574 p.

Lifanova, 2015 - Lifanova, T.Y. (2015). Interdisciplinary projects of Al-Farabi Kazakhstan National university in the field of media and information literacy. URL: http://unescokaznu.ucoz.kz/news/o_proektakh_kaznu_im_al_farabi_v_oblasti_medijnoj_i_informacionnoj_g ramotnosti/2018-01-09-499

Lisenko, 2008 - Lisenko, O. (2008). Military activity of Roman Shukhevych. Galichina. № 14: 27.

Lozitska, 2009 - Lozitska, T.Y. (2009). The use of media in the educational process through the eyes of young teachers. Herald of the Taras Shevchenko Luhansk National University. № 23. Part 2: 60-66.

Lozitska, 2010 - Lozitska, T.Y. (2010). Studying the attitude of teachers towards the media as a means of learning. Herald of the Taras Shevchenko Luhansk National University. № 17: 60-66.

Mamatova, 2015 - Mamatova, J., Sulaimanova, S. (2015). Uzbekistan on the path of development of media education. Tutorial. Tashkent: Extremum-press, $89 \mathrm{p}$.

Marchenko, 2018 - Marchenko, V. (2018). Colors of the banner of Stepan Bandera. Labyrinth of Times. № 5. http://www.hist.ru/bandera.html

Masterman, 1985 - Masterman, L. (1985). Teaching the Media. London: Comedia Publishing Group, 341 p.

Masterman, 1997 - Masterman, L. (1997). A Rational for Media Education. In: Kubey, R. (Ed.) Media Literacy in the Information Age. New Brunswick (U.S.A.) and London (UK): Transaction Publishers: 15-68.

Media education, 2012 - Media education, 2012. In: Great Russian Encyclopedia. Vol. 17. Moscow: The Great Russian Encyclopedia: 480.

Media..., 2016 - Media education in modern school: development of media literacy. Minsk, $337 \mathrm{p}$.

Mokroguz, 2013 - Mokroguz, O.P. (2013). On the issue of introduction of media education at school. Collection of articles of methodological seminar "Media education in Ukraine: scientific reflection of challenges, practices, perspectives". Kiev: National Academy of Pedagogical Sciences of Ukraine: 425-435.

Moroz, 2011 - Moroz, O.O. (2011). Media education: historical aspect of development. Educational Discourse. № 1 (3).

Moscow Declaration..., 2012 - Moscow Declaration on Media and Information Literacy. (2012). URL: http://www.ifapcom.ru/news/1347/?returnto=0,n=1

Muradyan, 2017 - Muradyan, A.S., Manukyan, A.M. (2017). Media literacy as a result of the use of animation technologies in the process of technological education. European journal of education and applied psychology. № 1: 14-19. 
Naidyonova, 2013 - Naidyonova, L.A. (2013). Main directions and first results of experimental implementation of media education at the national level. Collection of articles of the methodological seminar "Media education in Ukraine: scientific reflection of challenges, practices, perspectives". Kiev: National Academy of Pedagogical Sciences of Ukraine: 63-79.

Naidyonova, Barishpolts, 2008 - Naidyonova, L., Barishpolts, O. (eds.). Media culture of the Ukranian population: information bulletin. Kiev, $52 \mathrm{p}$.

Nuraliev, 2010 - Nuraliev, A. (2010). Problems and prospects of journalist education in Tajikistan in the light of the new standard of higher professional education. Journalism education - improvement of the quality of education and new technologies. Vienna: OSCE: 119-125.

Oleksyuk et al, 2009 - Oleksyuk, O.M., Shubenko, N.O. (2009). Experimental testing of the technology of developing the media culture of the future teacher of music by means of screen arts. Herald of the Taras Shevchenko Luhansk National University. №. 23 (186). Part 4: 77-87.

Onkovych, 2007 - Onkovych, G.V. (2007). Media education technologies. Higher Education in Ukraine. № 3-3, Vol. 5: 357-363.

Onkovych, 2008 - Onkovych, G.V. (2008). Media education as an intellectual and communicative network. Higher education of Ukraine in the context of integration into the European educational space. Kiev: 165-177.

Onkovych, 2009 - Onkovych, G.V. (2009). Mediology and media education: entrance to the science and education space. Language and culture. Issue 11. Vol. XII (124): 327-333.

Onkovych, 2009 - Onkovych, G.V. (2009). Use of the integrated knowledge space in the educational process by means of media education. Higher Education of Ukraine. № 2-1: 166 -172.

Onkovych, 2010 - Onkovych, G.V. (2010). Mediology. Scientific School of Roman Ivanchenko. Kiev: 119-128.

Onkovych, 2013 - Onkovych, G.V. (2013). Professionally oriented media education in high school. Collection of articles of the methodological seminar "Media education in Ukraine: scientific reflection of challenges, practices, perspectives. Kyiv: National Academy of Pedagogical Sciences of Ukraine: 79-89.

Onkovych et al., 2013 - Onkovych, G.V, Dukhanina, N.M, Sakhnevich, I.A. et al. (2013). Media didactics of universities: syllabi of special courses. Kiev.

Pocheptsov, 1999 - Pocheptsov, G.G. (1999). Theory and practice of information wars. Rivne: Volinski oberegi, $124 \mathrm{p}$.

Pocheptsov, 2000 - Pocheptsov, G.G. (2000). Information Wars. Kiev: Vakler, 280 p.

Pocheptsov, 2001 - Pocheptsov, G.G. (2001). How to "switch" the people. Psychological / information operations as technologies of influence on mass consciousness in the 2oth century. Kiev: Vakler.

Pocheptsov, 2011 - Pocheptsov, G.G. (2011). The theory of communication. Moscow: Reflbuk; Kiev: Vakler, 656 p.

Pocheptsov, 2015 - Pocheptsov, G.G. (2015). Propaganda 2.0: New dimensions in action. 5.07.2015. URL: http://ms.detector.media/trends/1411978127/propaganda_20_novye_ izmereniya_v_deystvii/

Polat, 2001 - Polat, E.S. (2001). Internet in humanities education. Moscow: Vlados.

Polonnikov, 2016 - Polonnikov, A. (2016). Can media education become an educational event? Educator. № 1 (26): 45-48.

Potter, 2016 - Potter, W.J. (2016). Media Literacy. L.A.: Sage, 676 p.

Potyatinik, 2004 - Potyatinik, B.V. (2004). Media: key to understanding. Lviv: Pais, 312 p.

Proceedings..., 2013 - International Scientific and Practical Internet Conference "Media education - priority direction in education of the XXIst century: problems, prospects and perspectives". Kharkiv: Kharkiv academy of continuous education, $268 \mathrm{p}$.

Propaganda..., 2016 - Propaganda, deepening the gap in mutual understanding (2016). Monitoring the media of the Eastern Partnership countries and Russia. Eastern Partnership Civil Society Forum, $47 \mathrm{p}$.

Pugach, 2011 - Pugach, S.I. (2011). Media education - an invariant component of the training content of a modern officer of the border guard service of the Republic of Belarus. Ideological aspects of military security. № 3: 38-39.

Report..., 2018 - Report on the results of the study of the level of media literacy in the Kyrgyz Republic (2018). Bishkek: Institute of Media Policy, 108 p. 
Robak, 2002 - Robak, V. (2002). Media Pedagogy: An Analysis of Innovative Foreign Experience. Dialogue of Cultures: Ukraine in the World Context: Philosophy of Education. Lviv: Spolom, Vol. 8: 70-92.

Sakhnevich, 2010 - Sakhnevich, I.A. (2010). Implementation of Media Education in Higher Educational Institutions in Ukraine: Problems and Prospects. Scientific Bulletin of the Volyn National University. № 21: 239-242.

Sakhnevich, 2010 - Sakhnevich, I.A. (2010). Workshop for independent mastering of basics of media competence. Methodical instructions and tasks for I-IV year students of technical specialties of oil and gas profile. Ivano-Frankivsk, $100 \mathrm{p}$.

Saveljeva, 2017 - Saveljeva, T.V. (2017). Media literacy of the pensioners of the XXI century. Sign. Problem field of media education. № 4: 209-212.

Scheibe, Rogow, 2012 - Scheibe, C., Rogow, F. (2012). The teacher's guide to media literacy: Critical thinking in a multimedia world. Thousand Oaks: Corwin.

Sharikov, 2005 - Sharikov, A.V. (2005). Social irresponsibility of television in Russia. Teleforum. 2005. № 1: 100-105; № 2:137-140.

Sharikov, 2012 - Sharikov, A.V. (2012). On the need for reconceptualization of media education. Media education. № 4: 61-76.

Sharko, 2012 - Sharko, O.I. (2012). The Discourse of Media Education Studies as Articulation of the Challenge of the Cultural Situation. Collection of Reports of the International Internet Conference "Information and Technology Support for the Educational Process of the CIS Member States". Minsk: 137-145.

Sheguta, 2013 - Sheguta, M. (2013). Media education (media literacy): realities, problems, perspectives. Materials of the International Scientific and Practical Internet Conference "Media Education - A Priority Direction in the Education of the 21st Century: Problems, Achievements and Prospects" (Kharkiv, October 25-27, 2013). Kharkiv: Kharkiv Academy of Continuing Education: 10-12.

Shturhezky, 2018 - Shturhezky, S. (2018). Media literacy: a practical textbook for higher education institutions on media and information literacy. Lyons: IREX Europe, 156 p. URL: http://www.mediasabak.org/media/IE_-_curriculum_-_university_V2_en.pdf

Silverblatt, 2001 - Silverblatt, A. (2001). Media Literacy. Westport, Connecticut - London: Praeger, $449 \mathrm{p}$.

Silverblatt, 2014 - Silverblatt, A. (2014). Media Literacy: Keys to Interpreting Media Messages. Santa Barbara: Praeger, 548 p.

Silverblatt et al, 2016 - Silverblatt, A., Fedorov A., Levitskaya A. (2016). Media literacy. Keys to interpreting media messages. NY: DIMLE. URL: http://www.dimle.org/home. php? page $=13$, idEccezione $=76$, id $=28$, idCo $=$

Soldatova, 2013 - Soldatova, G.V., Nestik, T.A., Rasskazova, E.I., Zotova, E.Y. (2013). Digital competence of teenagers and parents. The results of the All-Russian study. Moscow: Internet Development Fund, 144 p.

Spichkin, 1999 - Spichkin, A.V. (1999). What is media education. Kurgan, 114 p.

Spirina, 2013 - Spirina, E.A. (2013). Media education technologies of youth inculturation in the context of the modern media cultural space of Belarus. Herald of Belarus National University of Culture. № 2: 27-33.

Suryapi, 2016 - Suryapin, A. (2016). How do they teach media literacy in Ukraine, Moldova and Armenia. URL: https://baj.by/be/analytics/kak-v-ukraine-moldove-i-armenii-uchatmediagramotnosti

Tajidinnov et al, 2010 - Tajidinnov, D., Rustamov, S., Kosimov, R., Ibodova, P. (2010). Research on the state of introduction of ICT in the Republic of Tajikistan. Dushanbe, $101 \mathrm{p}$.

Teaching..., 2015 - Teaching media literacy for citizens. A handbook for coaches. (2015). Kiev: Academy of the Ukrainian Press, StopFake and IREX, 193 p.

The Act..., 1941 - The Act of Proclamation of Ukrainian Statehood (1941). Samostiyna Ukraina, July 10, p.1.

The experience..., 2017 - The experience of the Tver region in the cinema education of schoolchildren is presented at parliamentary educational hearings, 31.05.2017. URL: http: //минобр.верскаяобласть.pф/novosti/novosti/? print = y, ELEMENT_ID = 74904 
Trokhanyak, 2007 - Trokhanyak, N.A. (2007). Theoretical and methodological principles of development of media competence of future teachers. Scientific journal of the National Pedagogical University. Series 16. Issue 7 (17): 54-57.

Trokhanyak, 2008 - Trokhanyak, N.A. (2008). Foreign and domestic experience of the formation and development of media education. Herald of Lviv university. Issue 23: 55-62.

Trokhanyak, 2009 - Trokhanyak, N.A. (2009). Comparative analysis of media literacy among students of pedagogical specialties of Ukraine and Poland. Scientific works. Issue 5 (155). Part I: 40-45.

Tsymbalenko et al, 2006 - Tsymbalenko, S.B., Sharikov, A.V., Shcheglova, S.N. (2006). Information space of a Russian teenager in the post-Soviet period. Moscow.

UNESCO. 2001 - UNESCO (2001). Recommendations Addressed to the United Nations Educational Scientific and Cultural Organization UNESCO. In: Outlooks on Children and Media. Goteborg: UNESCO, NORDICOM, 2001, p. 152.

US..., 2018 - US intends to fight against the information influence of Russia in Central Asia (2018). Eurasia-Expert. URL: http://eurasia.expert/ssha-namereny-borotsya-protivinformatsionnogo-vliyaniya-rossii-v-tsentralnoy-azii/

Vardanyan, 2017 - Vardanyan, G. (2017). Russian "soft power" in Armenia. URL: http://newcaucasus.com/civil-hearings/16559-rossiyskaya-myagkaya-sila-v-armenii.html

Vartanova , Smirnova, 2010 - Vartanova, E.L. , Smirnova, O.V. (eds.) (2010). Media Education in School: A Collection of Syllaby. Moscow: MediaMir, 320 p.

Vartanova et al, 2003 - Vartanova, E.L., Zasursky, Y.N. (2003). Russian module of media education: concepts, principles, models. Information Society. 2003. № 3: 5-10.

Vasyanovich, 2007 - Vasyanovich, G. (2007). Media educaion: foreign and domestic experience. Pedagogics and psychology of vocational education. № 2: 11-21.

Venidiktov, 2015 - Venidiktov, S.V. (2015). Integration resource of media education in the Eurasian project. Academic Herald of Belgorod State University. №18 (215). Issue. 27: 190-196.

Venidiktov, 2017 - Venidiktov, S.V. (2017). Development of civil media education in the Eurasian Economic Union. Sign: a problem field of media education. № 1 (23). URL: https://cyberleninka.ru/article/n/razvitie-grazhdanskogo-mediaobrazovaniya-v-evraziyskomekonomicheskom-soyuze

Voloshenyuk et al, 2017 - Voloshenyuk, O., Degtyaryova, G., Ivanov, V. (eds.) (2017). Media literacy and critical thinking in elementary schools: teachers' manual. Kiev, $197 \mathrm{p}$.

Voloshina, 2010 - Voloshina, A.K., Voloshina, K.O. (2010). Formation of teacher's media competence through audiovisual technologies. Actual problems of Slavic philology. Issue. XXIII. Part 1: 510-517.

Vozchikov, 2007 - Vozchikov, V.A. (2007). Mediosphere of the philosophy of education. Biysk: Biysk state pedagogical university, $284 \mathrm{p}$.

Zadorin et al, 2017 - Zadorin, I.V., Maltseva, D.V., Shubina, L.V. (2017). Level of media literacy in the regions of Russia: comparative analysis. Communications. Media. Design. Vol. 2. № 4: 123-141. URL: http://www.zircon.ru/upload/iblock/945/7477-qcdefault.genres.articleqa10381-1-10-20180330.pdf

Zakharchuk, 2010 - Zakharchuk, T. (2010). Application of media education technologies in the professional training of a teacher-philologist. Humanization of the educational process. Special Issue 5: 145-151.

Zavalko, Sakhariyeva, 2013 - Zavalko, N., Sakhariyeva, S. (2013). Development of teachers' media competence in the distance learning. Environment international journal of experimental education. № 2, pp. 36-39.

Zaznobina, 1998 - Zaznobina, L.S. (1998). The standard of media education integrated into the humanities and natural science disciplines of primary and secondary general education. URL: www.mediaeducation.ru

Zhilinskaya, 2008 - Zhilinskaya, T.S. (2008). Media education of post graduate students: theoretical concepts and methodological approaches. Proceedings of the international scientific and practical conference "Innovations and training of post graduates in the Republic of Belarus and abroad". Minsk: BelISA.

Zhizhina, 2009 - Zhizhina, M.V. (2009). Media culture: cultural and psychological aspects. Moscow: Vuzovskaya Kniga, 188 p. 
Zhurin, 2009 - Zhurin, A.A. (2009). Integrated media education in secondary school (subjects of natural sciences). Moscow-Sarov, $300 \mathrm{p}$.

\section{Appendix}

"The Act of Proclamation of Ukrainian Statehood

1. By the will of the Ukrainian people, the Organization of Ukrainian Nationalists under the direction of Stepan Bandera proclaims the formation of the Ukrainian State for which have laid down their heads whole generations of the finest sons of Ukraine.

The Organization of Ukrainian Nationalists, which under the direction and founder and leader Yevhen Konovalets has undertaken in the past ten years a bloody battle with the Moscovite-Bolshevikenslavers in an energetic battle for freedom, calls all the Ukrainian people not to place down its weapons until all Ukrainian lands are united to form a Sovereign Ukrainian Government.

The Sovereign Ukrainian Government will guarantee Ukrainian people order, unilateral development of all its energies and all its needs.

2. In the western lands of Ukraine a Ukrainian Government is formed, which is subordinate to the Ukrainian National Government that will be formed in the capital of Ukraine - Kiev.

3. The newly formed Ukrainian state will work closely with the National-Socialist Greater Germany, under the leadership of its leader Adolf Hitler which is forming a new order in Europe and the world and is helping the Ukrainian People to free itself from Moscovite occupation.

The Ukrainian People's Revolutionary Army which has been formed on the Ukrainian lands, will continue to fight with the Allied German Army against Moscovite occupation for a sovereign and united State and a new order in the whole world.

Long live the Ukrainian Sovereign United Ukraine! Long live the Organization of Ukrainian Nationalists! Long live the leader of the Organization of Ukrainian Nationalists and the Ukrainian people - Stepan Bandera.

Glory to Ukraine!

(Signed) Yaroslav Stezko - Head of the National Assembly"

Source: the Newspaper "Samostiyna Ukraina" published in Stanislaviv, July 10, 1941, p. 1. 